\title{
Appraisal of International Guidelines for Cancer Pain Management
}

\author{
Miran Kim, Sarah Yeun-Sim Jeong \\ School of Nursing and Midwifery, University of Newcastle, Australia
}

Purpose: Given that healthcare professionals need to use relevant data bases to access and manage information that informs their practice, this paper reports on a review of processes within the development and use of international guidelines for pain management for cancer patients and considers the implications for nurse education and practice.

Methods: An integrative systematic approach to a review of the literature around the development and implementation of guidelines for pain management by nurses.

Results: The literature review reveals that using evidence from research to optimally perform the nursing role in pain management is essential. However, clear statements of the scope of nursing practice within formal guidelines are also necessary; problems about use of Evidence-based Guidelines (EBGs) stem from the lack of detail on the nursing contribution in the development and implementation of guidelines themselves and other factors/barriers impeding the application of guidelines to education and practice.

Conclusion: Nurses need to contribute to guideline development if they are to fully appreciate their role in pain management and consider the contribution to decision-making around learning processes aligned to nursing care. Clear evidence of the manner in which guidelines are developed and updated is necessary if they are to be seen as inclusive of all healthcare professionals.

Keywords: Cancer pain management; Evidence-based guidelines; Nursing

\section{INTRODUCTION}

Given that the National Cancer Control Institute (NCCI, 2017) reported that cancer was the leading cause of death in Korea with one in every four people diagnosed with cancer, it follows that stimulus material be included in curricula including that within problem or practice-based learning (PBL). Learning activities would also centre on the need for use of the best evidence for practice around the management of pain as a symptom. PBL advocates education that is both informed by and informs contemporary practice; the PBL methodology encourages the healthcare professional students to be information fluent, to use relevant data bases as a source of the best available evidence to inform safe and effective care.

Patients with cancer suffer from the disease and its treatment, and many also suffer with unrelieved and intractable pain (Byun \& Choi, 2013). The relief of cancer pain is recognised as the most significant issue in cancer care and a key area for improvement in order to enhance quality of life among the patients with cancer and their families in both national and international contexts. Nurses are central to the management of pain related to cancer and like other healthcare professionals need to keep abreast of changes in practice based on the best evidence available. The use of evidence-based guidelines (EBGs), as a model of patient care for people with cancer, is considered an essential element in improving care quality through improving patient outcomes (Bhatnagar \& Gupta, 2015; Dy et al., 2008).

Successful dissemination of an EBG requires strategies for use and uptake by all stakeholders

(C) Copyright 2019 International Society for Problem-Based Learning

(c) This is an Open Access article distributed under the terms of the Creative Commons Attribution Non-Commercial License (http://creativecommons.org/licenses/ by-nc/4.0/) which permits unrestricted non-commercial use, distribution, and reproduction in any medium, provided the original work is properly cited. 
including nurses. The World Health Organisation (WHO) report suggests that all healthcare professionals need to be given opportunities to be involved in developing an EBG and embedding evidence into professional practice and education (WHO, 2017). For example, dissemination of guidelines to nurses who are involved in pain management requires appropriate educational strategies to translate the guidelines into their practice (Medves et al., 2010; Powell et al., 2017). However, in reality, two studies by Cho (2009) and Yu (2011) investigated nurses' knowledge about and performance with cancer pain management. They reported that it was not clear how nursing practice was influenced by any guidelines. Van den Beuken-van Everdingen et al. (2016) also pointed out in their systematic review that despite the effort to encourage use of guidelines to improve patient outcomes around pain management, there was little evidence showing improvement in the study settings including acute settings. Baatiema et al. (2017) argue that the uptake and adoption of EBGs are often delayed or fail because of a range of barriers across organisational healthcare professional domains, patient care and policies (guidelines). There is some evidence about the barriers, facilitators and interventions that impact on the uptake of evidence from systematic reviews (Wallace, Byrne, \& Clarke, 2014). Little is known about what constitutes high quality in guidelines themselves and how this may impact on the uptake of guidelines, although development of guidelines with high quality is one of the fundamental influential factors.

Given that healthcare professionals need to use relevant data bases to access and manage information that informs their practice, this paper aims to provide an exemplar of how to conduct a review on EBGs, in this case, cancer pain management guidelines, and discuss the implications for nurse education and practice.

\section{METHODS}

The search for 'Guidelines' was conducted first through the reference list of the report of Green et al. (2010), then a more extensive online search for the cancer pain management guidelines followed. Only four guidelines were cancer pain management focused in the review by Green et al. (2010). The American Pain Society [APS]'s 'Guideline for the management of cancer pain in adults and children' was not available in the full version, because these guidelines were no longer viewed as guidance for current medical practice, and are archived (APS, 2004). Three guidelines; The 'Cancer pain management manual' (Canadian Association of Nurses in Oncology [CANO], 2004), the 'Guidelines for the management of cancer-related pain in adults' of the Cancer Care Nova Scotia (CCNS) (Cancer Care Nova Scotia, 2005), and the 'Control of pain in patients with cancer: a national clinical guide- line' (Scottish Intercollegiate Guidelines Network [SIGN], 2008) were selected for review. The 'NCCN Clinical Practice Guidelines in Oncology: Adult Cancer Pain' (NCCN, 2017), 'Best Practice Statement: The management of pain in patients with cancer' (NHS Quality Improvement Scotland, 2009) and 'Cancer Pain Management in Adults' (AACPMGWP, 2016) were also selected and reviewed.

Cancer Care Ontario's Cancer-related Pain Management Guideline Panel conducted a systematic review of pain management guidelines using the Appraisal of Guideline Research and Evaluation I (AGREE I); eight guidelines of a set of twenty-five were finally evaluated (Green et al., 2010). They developed an evidence-base and achieved consensus on recommendations for practice. Green et al. (2010) recommended 11 elements for inclusion in cancer pain management guidelines - "assessment of pain; assessors of pain; time and frequency of assessment; components of pain assessment; assessment of pain in special populations; plan of care; pharmacologic intervention; non-pharmacologic intervention; documentation; education; and outcome measurement of cancer pain management". They emphasised patient and family centred care, customised care and an interdisciplinary team approach to provide optimal cancer pain management. Those recommended elements are also reflective of others that the internationally recognised EBGs should include such as an inter-professional and collaborative approach, person centred care (PCC), use of evidence-based assessment tools, trusting patients' self-reports of pain, and the use of pharmacological and non-pharmacological interventions. The review of further international guidelines for cancer pain management were guided by those recommendations (See Table 1).

The AGREE II criteria (Brouwers et al., 2010) were used as this was the most recent version available focussing on the quality of guidelines. The researcher endeavoured to find relevant information about each guideline development process prior to undertaking the appraisal as not every guideline report included a description of how the guideline was developed; it was often difficult to obtain a sufficient level of information to retrieve the entire process. There were times when the researcher had to skip certain items or rate the item as 1 (lower possible quality) and consider it as absence of information as instructed by the user's manual. It required at least two reviewers to individually assess and come to a consensus about decisions for recommending each guideline. Therefore, two authors were involved in appraising the quality of guidelines. Decisions on the scores for each domain for each individual guideline is presented in Table 2. 


\section{RESULTS}

Based on recommendations of Green et al. (2010), selected guidelines have been reviewed for appropriate content (Table 1). No single international guideline had all 11 recommended elements of content and most guidelines did not have outcome measurements.

The quality as EBGs was also reviewed using AGREE II (Brouwers et al., 2010) domains: Scope and purpose; stakeholder involvement; rigour of development; clarity of presentation; applicability; and editorial independence (Table 2). There were domains with a low score, and because of the presence of a 'Not Ap- plicable' option, the item was rated as 1 . Despite the low rating for some domains, the reviewed guidelines were considered as 'strongly recommended', because there was no set of minimum domain scores or patterns of scores to differentiate between high and poor quality guidelines. In this situation, the AGREE II Consortium suggested that decisions made by the user needed consideration of the context, when the AGREE II was used (Table 3).

Clear statements of the scope and the purposes of the guidelines are essential. They include the overall aim, which informs the goal of nursing care; specific health topics, pain management for the patients with cancer; and the target population for whom the guidelines are to be used. This should prompt the nurses to consider the

Table 1. Review list of guidelines for cancer pain management

\begin{tabular}{|c|c|c|c|c|c|c|c|}
\hline & & CANO (2004) & CCNS (2005) & SIGN (2008) & NCCN (2017) & NHS (2009) & AACPMGWP (2016) \\
\hline \multirow{12}{*}{ Recommendations } & AGREE Score & $\begin{array}{l}\text { Strongly } \\
\text { recommended }\end{array}$ & $\begin{array}{l}\text { Strongly } \\
\text { recommended }\end{array}$ & $\begin{array}{c}\text { Strongly } \\
\text { recommended }\end{array}$ & $\begin{array}{l}\text { Strongly } \\
\text { recommended }\end{array}$ & $\begin{array}{l}\text { Strongly } \\
\text { recommended }\end{array}$ & $\begin{array}{c}\text { Strongly } \\
\text { recommended }\end{array}$ \\
\hline & Assessment of pain & Yes & Yes & Yes & Yes & Yes & Yes \\
\hline & Assessors of pain & Yes & Yes & Yes & Yes & Yes & Yes \\
\hline & $\begin{array}{l}\text { Timing/ frequency of } \\
\text { assessment }\end{array}$ & No & Yes & Yes & Yes & No & Yes \\
\hline & $\begin{array}{l}\text { Components of pain } \\
\text { assessment }\end{array}$ & Yes & Yes & Yes & Yes & Yes & Yes \\
\hline & $\begin{array}{l}\text { Assessment of pain in } \\
\text { special populations }\end{array}$ & Yes & Yes & Yes & No & No & Yes \\
\hline & Plan of care & Yes & Yes & No & Yes & No & No \\
\hline & $\begin{array}{l}\text { Pharmacological } \\
\text { intervention }\end{array}$ & Yes & Yes & Yes & Yes & Yes & Yes \\
\hline & $\begin{array}{l}\text { Non-pharmacological } \\
\text { intervention }\end{array}$ & Yes & Yes & Yes & Yes & Yes & Yes \\
\hline & Documentation & Yes & Yes & No & No & No & Yes \\
\hline & Education & No & Yes & Yes & Yes & Yes & Yes \\
\hline & Outcome measures & No & No & No & Yes & No & No \\
\hline
\end{tabular}

CANO, Canadian Association of Nursing Oncology; CCNS, Cancer Care Nova Scotia; SIGN, Scottish Intercollegiate Guidelines Network; NCCN, National Comprehensive Cancer Network ; NHS, National Health Service Quality Improvement Scotland; CGW, Cancer Guidelines Wiki

Table 2. Appraisal for cancer pain management related guidelines using AGREE II

\begin{tabular}{|c|c|c|c|c|c|c|c|}
\hline \multirow[b]{2}{*}{ Guideline } & \multicolumn{6}{|c|}{ Domains (\%) } & \multirow[b]{2}{*}{ Overall } \\
\hline & $\begin{array}{l}\text { Scope \& } \\
\text { Purpose }\end{array}$ & $\begin{array}{l}\text { Stakeholder } \\
\text { Involvement }\end{array}$ & $\begin{array}{c}\text { Rigour of } \\
\text { Development }\end{array}$ & $\begin{array}{c}\text { Clarity of } \\
\text { Presentation }\end{array}$ & Applicability & $\begin{array}{c}\text { Editorial } \\
\text { Independence }\end{array}$ & \\
\hline CANO (2004) & 81 & 61.9 & 39.3 & 90.5 & 39.3 & 21.4 & $\begin{array}{l}\text { Strongly } \\
\text { recommended }\end{array}$ \\
\hline CCNS (2005) & 100 & 76.2 & 66.1 & 85.7 & 50 & 78.6 & $\begin{array}{c}\text { Strongly } \\
\text { recommended }\end{array}$ \\
\hline SIGN (2008) & 100 & 90.5 & 91.1 & 95.2 & 75 & 14.3 & $\begin{array}{c}\text { Strongly } \\
\text { recommended }\end{array}$ \\
\hline NCCN (2017) & 85.7 & 57.1 & 67.9 & 71.4 & 28.6 & 35.7 & $\begin{array}{c}\text { Strongly } \\
\text { recommended }\end{array}$ \\
\hline NHSOIS (2009) & 81 & 66.7 & 35.7 & 85.7 & 46.4 & 14.3 & $\begin{array}{c}\text { Strongly } \\
\text { recommended }\end{array}$ \\
\hline ACPMGWP (2016) & 81 & 76.2 & 71.4 & 90.5 & 57.1 & 92.9 & $\begin{array}{l}\text { Strongly } \\
\text { recommended }\end{array}$ \\
\hline
\end{tabular}


special circumstances of this particular group of patients (Brouwers et al., 2010). The reviewed international guidelines for managing cancer pain clearly presented their scope and purposes.

The CCNS guidelines (Cancer Care Nova Scotia, 2005) noted that guidelines should be able to support all healthcare profession- als, including nurses working in a variety of settings with their decision making; they should contain a certain level of recommended evidence-based information about a range of issues in cancer pain management.

There should also be evidence of how the set of guidelines was

Table 3. Key items of AGREE II and their application on appraisal of guidelines

\begin{tabular}{|c|c|c|c|c|c|c|c|}
\hline & Key items & $\begin{array}{l}\text { CANO } \\
(2004)\end{array}$ & $\begin{array}{l}\text { CCNS } \\
(2005)\end{array}$ & $\begin{array}{l}\text { SIGN } \\
(2008)\end{array}$ & $\begin{array}{l}\text { NCCN } \\
(2017)\end{array}$ & $\begin{array}{l}\text { ACPMGWP } \\
(2016)\end{array}$ & $\begin{array}{l}\text { NHSOIS } \\
(2009)\end{array}$ \\
\hline \multirow[t]{3}{*}{$\begin{array}{l}\text { Domain I Scope \& } \\
\text { Purpose }(21 / 3)\end{array}$} & $\begin{array}{l}\text { 1. The overall objective(s) of the guideline is (are) } \\
\text { specifically described. }\end{array}$ & 5 & 7 & 7 & 6 & 6 & 6 \\
\hline & $\begin{array}{l}\text { 2. The health question(s) covered by the guideline } \\
\text { is (are) specifically described. }\end{array}$ & 6 & 7 & 7 & 6 & 5 & 5 \\
\hline & $\begin{array}{l}\text { 3. The population (patients, public, ect.) to whom } \\
\text { the guideline is meant to apply is specifically } \\
\text { described. }\end{array}$ & $6(81)$ & $7(100)$ & $7(100)$ & $6(85.7)$ & $6(81)$ & $6(81)$ \\
\hline \multirow[t]{3}{*}{$\begin{array}{l}\text { Domain II Stakeholder } \\
\text { Involvement (21/3) }\end{array}$} & $\begin{array}{l}\text { 4. The guideline development group includes } \\
\text { individuals from all relevant professional } \\
\text { groups. }\end{array}$ & 4 & 4 & 7 & 5 & 5 & 4 \\
\hline & $\begin{array}{l}\text { 5. The views and preferences of the target } \\
\text { population (patients, public, ect.) have been } \\
\text { sought. }\end{array}$ & 2 & 5 & 5 & 1 & 5 & 6 \\
\hline & $\begin{array}{l}\text { 6. The target users of the guideline are clearly } \\
\text { defined. }\end{array}$ & 7 (61.9) & 7 (76.2) & 7 (90.5) & $6(57.1)$ & $6(76.2)$ & $4(66.7)$ \\
\hline \multirow[t]{8}{*}{$\begin{array}{l}\text { Domain III Rigour of } \\
\text { Development (56/8) }\end{array}$} & $\begin{array}{l}\text { 7. Systematic methods were used to search for } \\
\text { evidence. }\end{array}$ & 4 & 4 & 6 & 6 & 5 & 2 \\
\hline & $\begin{array}{l}\text { 8. The criteria for selecting the evidence are } \\
\text { clearly described. }\end{array}$ & 2 & 2 & 6 & 5 & 6 & 1 \\
\hline & $\begin{array}{l}\text { 9. The strengths and limitations of the body of } \\
\text { evidence are clearly described. }\end{array}$ & 2 & 2 & 7 & 6 & 2 & 1 \\
\hline & $\begin{array}{l}\text { 10. The methods for formulating the } \\
\text { recommendations are clearly described. }\end{array}$ & 2 & 5 & 7 & 4 & 5 & 1 \\
\hline & $\begin{array}{l}\text { 11. The health benefits, side effects and risks } \\
\text { have been considered in formulating the } \\
\text { recommendations. }\end{array}$ & 5 & 6 & 5 & 5 & 6 & 5 \\
\hline & $\begin{array}{l}\text { 12. There is an explicit link between the } \\
\text { recommendations and the supporting } \\
\text { evidence. }\end{array}$ & 5 & 5 & 6 & 5 & 6 & 4 \\
\hline & $\begin{array}{l}\text { 13. The guideline had been externally reviewed by } \\
\text { experts prior to its publication. }\end{array}$ & 1 & 2 & 7 & 1 & 6 & 4 \\
\hline & $\begin{array}{l}\text { 14. A procedure for updating the guideline is } \\
\text { provided. }\end{array}$ & 1 (39.3) & $6(66.1)$ & 7 (91.1) & $6(67.9)$ & 4 (71.4) & $2(35.7)$ \\
\hline \multirow[t]{3}{*}{$\begin{array}{l}\text { Domain IV Clarity of } \\
\text { Presentation }(21 / 3)\end{array}$} & $\begin{array}{l}\text { 15. The recommendations are specific and } \\
\text { unambiguous. }\end{array}$ & 6 & 7 & 7 & 5 & 6 & 6 \\
\hline & $\begin{array}{l}\text { 16. The different options for management of the } \\
\text { condition or health issue are clearly presented. }\end{array}$ & 7 & 5 & 7 & 5 & 7 & 6 \\
\hline & 17. Key recommendations are easily identifiable. & $6(90.5)$ & $6(85.7)$ & $6(95.2)$ & $5(71.4)$ & $6(90.5)$ & $6(85.7)$ \\
\hline \multirow{4}{*}{$\begin{array}{l}\text { Domain V Applicability } \\
(28 / 4)\end{array}$} & $\begin{array}{l}\text { 18. The guideline describes facilitators and barriers } \\
\text { to its application. }\end{array}$ & 1 & 2 & 5 & 1 & 4 & 4 \\
\hline & $\begin{array}{l}\text { 19. The guideline provides advice and/or tools on } \\
\text { how the recommendations can be put into } \\
\text { practice. }\end{array}$ & 7 & 5 & 7 & 4 & 6 & 2 \\
\hline & $\begin{array}{l}\text { 20. The potential resource implications of applying } \\
\text { the recommendations have been considered. }\end{array}$ & 2 & 2 & 2 & 2 & 4 & 1 \\
\hline & $\begin{array}{l}\text { 21. The guideline presents monitoring and/or } \\
\text { auditing criteria. }\end{array}$ & $1(39.3)$ & $5(50)$ & $7(75)$ & $1(28.6)$ & $2(57.1)$ & $6(46.4)$ \\
\hline \multirow{2}{*}{$\begin{array}{l}\text { Domain VI Editorial } \\
\text { Independence (14/2) }\end{array}$} & $\begin{array}{l}\text { 22. The views of the funding body have not } \\
\text { influenced the content of the guideline. }\end{array}$ & 1 & 5 & 1 & 4 & 6 & 1 \\
\hline & $\begin{array}{l}\text { 23. Competing interest of guideline development } \\
\text { group members have been recorded and } \\
\text { addressed. }\end{array}$ & $2(21.4)$ & $6(78.6)$ & $1(14.3)$ & $1(35.7)$ & 7 (92.9) & $1(14.3)$ \\
\hline
\end{tabular}


developed and updated, but some of the guidelines did not have sufficient information on 'Rigour of development'. This domain was to provide explanations including how each recommendation in the guidelines was made based on evidence.

\section{DISCUSSION AND CONCLUSIONS}

Meaningful evidence should inform nurse education and practice around pain management. Any educative health professional initiative around pain management needs to reflect contemporary contexts, be reliant on 'showcasing' professional behaviour in response to stimulus material that is based on the best available evidence. Professional nurses also need to critique the worthiness and suitability of guidelines advocated for use in their daily practice. Nurses are able to provide patient-centred narratives on their experiences with pain. These are well suited for use within guideline development and testing, and as stimulus material in problem/practice or enquiry-based learning programs. In order to achieve quality management of cancer pain, nurses must play a pivotal role as a part of an interdisciplinary team Dowding et al. (2016). show how nurses make critical nursing decisions at every step of their practice. If researchers and policy makers are to value the nursing contribution, nurses managing pain among the patients with cancer must be less task-solving oriented, less passive and medically dependent.

There could be several influential factors that underpin the nursing contribution in the development of guidelines to inform the current place of nursing practice in managing cancer pain. These include historical, social and cultural images of nurses; legal boundaries of nurses' scope of practice; and the absence of a nursing framework for management of the particular symptom. Those factors are contributors to the conscious and unconscious undervaluing of nursing not only among medical officers and patient/families, but also among nurses themselves (Kim, 2019). This negative profile of the profession is undermining positive perceptions of what nurses do in caring for those patients with cancer especially around policy and practices in pain management (Kim, 2019).

Practice or problem-based learning (PBL) underpins a student-centred pedagogy to enhance their ability to make critical decisions (Ahn \& Kang, 2017), when they face complex clinical situations including cancer pain management. As Yew and Goh (2016) state learners including nurses involved with PBL are considered as active knowledge seekers and co-creators who use their experiences and knowledge to organise the solutions to solve the problems such as cancer pain management. It is essential to identify the best evidence to help solving problems and use the evidence to inform their own nursing practice.
Use of EBGs in nursing practice is considered as an effective way of making critical nursing decisions based on evidence. Therefore, the need for evidence-based nursing practice using EBGs has increased significantly (Choi et al., 2014) and is now considered as nurses' ethical responsibility (Oncology Nursing Society, 2017). This indicates that developing guidelines in a systematic way, based on evidence from the nursing literature is a fundamental step of establishing EBGs in nursing practice for cancer pain management.

In this review, the authors used the outcomes of the integrated systematic review on same issues as the criteria for reviewing content of further guidelines, along with the use of a tool to review the quality of the guidelines. This process could ensure that the further development and/or updating of EBGs for pain management for cancer patients leads to revisions that are reliable and strong, and inclusive of meaningful nursing interventions.

The review of the guidelines suggested that there was a need for greater contribution from nurses in their development. It follows that South Korean nurses need to be more involved in considering amplification of their important role in pain management. Curriculum models using PBL provide a useful platform for showcasing stimulus material that focusses on the nursing role in pain management.

\section{NOTES}

\section{Research Ethics}

This review was a part of doctoral studies (Ethics approval No. H-2012-0071) undertaken by Miran Kim.

\section{ACKNOWLEDGEMENTS}

This research was supported by an Australian Government Research Training Program (RPT) Scholarship.

\section{REFERENCES}

Ahn, H. R., \& Kang, K. S. (2017). Effects of problem-based learning $(\mathrm{PBL})$ applied in community health nursing practicum on critical thinking disposition and learning motivation of nursing students. Journal of the Korea Entertainment Industry Association, 11(7), 315-322.

American Pain Society. (2004). Guideline for the management of cancer pain in adults and children. Retrieved from http://apps. americanpainsociety.org/store/product-details?Produc$\mathrm{tId}=472$

Australian Adult Cancer Pain Management Guideline Working Party. (2016). Cancer pain management in adults. Retrieved from http://wiki.cancer.org.au/australia/Guidelines:Cancer_pain 
management/Patient-centred_care

Baatiema, L., Otim, M. E., Mnatzaganian, G., Aikins, A. d.-G., Coombes, J., \& Somerset, S. (2017). Health professionals' views on the barriers and enablers to evidence-based practice for acute stroke care: A systematic review. Implementation Science, 12(74).

Bhatnagar, S., \& Gupta, M. (2015). Evidence-based clinical practice guidelines for interventional pain management in cancer pain. Indian Journal of Palliative Care, 21(2), 137-147.

Brouwers, M. C., Kho, M. E., Browman, G. P., Burgers, J. S., Cluzeau, F., \& Feder, G., et al. (2010). AGREE II: Advancing guideline development, reporting and evaluation in health care. Canadian Medical Association Journal, 182(18), E829-842.

Brouwers, M. C., Kho, M. E., Browman, G. P., Burgers, J. S., Cluzeau, F., \& Feder, G., et al. (2010). Development of the AGREE II, part 2: Assessment of validity of items and tools to support application. Canadian Medical Association Journal, 182(10), E472E478.

Byun, J. S., \& Choi, J. Y. (2013). Pain intensity, pain control ald pain control barriers between cancer patients and their nurses. Asian Oncology Nursing, 13(4), 287-294.

Canadian Association of Nurses in Oncology. (2004). CANO Cancer pain management manual. Retrieved from http://www.cano-acio.ca

Cancer Care Nova Scotia. (2005). Best practice guidelines for the management of cancer-related pain in adults. Retrieved from http://www.cancercare.ns.ca/site-cc/media/cancercare/PainGuidelineFVDec05.pdf

Cho, E. K. (2009). Nurses' knowledge and performance of cancer pain management. Unpublished master's thesis, Keimyung University, Daegu.

Choi, M., Kim, H. S., Chung, S. K., Ahn, M. J., Yoo, J. Y., \& Park, O. S., et al. (2014). Evidence-based practice for pain management for cancer patients in an acute care setting. International Journal for Nursing Practice, 20(1), 60-69.

Dowding, D., Lichtner, V., Allcock, N., Briggs, M., James, K., \& Keady, J., et al. (2016). Using sense-making theory to aid understanding of the recognition, assessment and management of pain in patients with dementia in acute hospital settings. International Journal of Nursing Studies, 53, 152-162.

Dy, S. M., Asch, S. M., Naeim, A., Sanati, H., Walling, A., \& Lorenz, K.A. (2008). Evidence-based standards for cancer pain management. Journal of Clinical Oncology, 26(23), 3879-3885.

Green, E., Zwaal, C., Beals, C., Fitzgerald, B., Harle, I., \& Jones, J., et al. (2010). Cancer-related pain management: A report of evidence-based recommendations to guide practice. Clinical Journal of Pain, 26(6), 449-462.

Kim, M. (2019). The uptake of guidelines for cancer pain manag- meent and its impact on nursing practice in South Korea: A critical Ethnography. Unpublished doctoral dissertation, University of Newcastle, Australia.

Medves, J., Godfrey, C., Turner, C., Paterson, M., Harrison, M., \& MacKenzie, L., et al. (2010). Systematic review of practice guideline dissemination and implementation strategies for healthcare teams and team-based practice. International Journal Of Evidence-Based Healthcare, 8(2), 79-89.

National Cancer Control Institute. (2017). NCCI: National cancer control programs. Retrieved from http://www.ncc.re.kr/main. ncc? uri = english/sub04_ControlPrograms

National Comprehensive Cancer Network. (2017). NCCN clinical practice guidelines in oncology: Adult cancer pain. Retrieved from http://www.nccn.org/professionals/physician_gls/pdf/ pain.pdf

NHS Quality Improvement Scotland. (2009). Best practice statement-The management of pain in patients with cancer. Retrieved from http://www.healthcareimprovementscotland.org/previous_resources/best_practice_statement/cancer_pain_management.aspx

Oncology Nursing Society. (2017). Position statement- Cancer pain management. Retrieved from http://www.ons.org/advocacy-policy/positions/practice/pain-management

Powell, B., Beidas, R., Lewis, C., Aarons, G., McMillen, J., \& Proctor, E., et al. (2017). Methods to improve the selection and tailoring of implementation strategies. Journal of Behavioral Health Services \& Research, 44(2), 177-194.

Scottish Intercollegiate Guidelines Network. (2008). Control of pain in adults with cancer: A national clinical guideline. Retrieved from http://www.sign.au.uk

Van den Beuken-van Everdingen, M. H. J., Hochstenbach, L. M. J., Joosten, E. A. J., Tjan-Heijnen, V. C. G., \& Janssen, D. J. A. (2016). Update on prevalence of pain in patients with cancer: Systematic review and meta-analysis. Journal of Pain and Symptom Management, 51(6), 1070-1090.e1079.

Wallace, J., Byrne, C., \& Clarke, M. (2014). Improving the uptake of systematic reviews: A systematic review of intervention effectiveness and relevance. BMJ Open, 4(10), 1-13.

World Health Organisation. (2017). Facilitating evidence-based practice in nursing and midwifery in the WHO European region. Copenhagen: WHO Regional Office for Europe.

Yew, E. H. J., \& Goh, K. (2016). Problem-Based Learning: An Overview of its Process and Impact on Learning. Health Professions Education, 2(2), 75-79.

Yu, H. J. (2011). Hospice ward and medical ward nurses' knowledge and performance of cancer pain management. Unpublished master's thesis, Hanyang University, Seoul. 